João Antonio de Moraes, Eloísa Benvenutti de Andrade:

\title{
Who are the citizens of the digital citizenship?
}

\begin{abstract}
:
We live in the Digital Era, where national frontiers are vanishing. In light of cultural globalization and digital identity, a contemporary re-interpretation of classical notions like citizenship is imperative. What does it mean to be a citizen in the Digital Era? To whom can we assign digital citizenship status? In order to discuss these questions we introduce the notion of hybrid beings. Our hypothesis is that the dynamical feedback relation between the physical and digital individual's experience promotes the embodiment of a hybrid identity from which the hybrid being emerges. It is important to stress that the hybrid identities of hybrid beings are not just alter egos or avatars created in the digital world, but that they express a new dynamic around the impossibility of distinguishing between "physical" and "digital" sides of an individuals' actions. It is precisely because of a hybrid being's participation in a merged physical/digital world that we believe the notion of hybrid beings is the most suitable paradigm to exemplify the role of the digital citizen and digital citizenship.
\end{abstract}

\section{Agenda:}

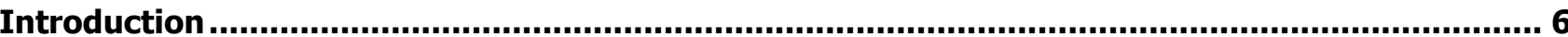

Traditional Citizenship ..................................................................................................................... 7

ICT and Hybrid Beings ....................................................................................................... 10

Popular Participation and the Fifth Estate...................................................................... 13

Final Considerations................................................................................................................ 16

\section{Authors:}

João Antonio de Moraes:

- $\quad$ PhD Candidate in Philosophy at State University of Campinas, UNICAMP, Campinas/São Paulo/Brazil.

- $\bowtie$ moraesunesp@yahoo.com.br

- Relevant publications:

- João Antonio de Moraes, Eloísa Benvenutti de Andrade. Notas para uma Fenomenologia da Vida Informacional. In: Mariana Claudia Broens, João Antonio de Moraes, Edna Alves de Souza (Eds.). Informação, Complexidade e Auto-Organização: Estudos Interdisciplinares. Campinas: Coleção CLE, v.73, p. 115-132, 2015.

- Leonardo Ferreira Almada, João Antonio de Moraes. Uma análise filosófica sobre o problema da privacidade informacional e suas implicações legais. Perspectivas em Ciências Tecnológicas, v.4, n. 4, p.1-24, 2015.

- $\quad$ Fred Adams, João Antonio de Moraes. Is there a Philosophy of Information? TOPOI - An International Review on Philosophy. Springer, 2014 (Online First). DOI: 10.1007/s11245-0149252-9 
- João Antonio de Moraes. Implicações éticas da "virada informacional na filosofia". Uberlândia: EDUFU, 2014.

- Maria Eunice Quilici Gonzalez, João Antonio de Moraes. Complexidade e privacidade informacional: um estudo na perspectiva sistêmica. In: Ettore Bresciani Filho, Maria Eunice Quilici Gonzalez, Ramon Capelle Souza de Andrade, Ana Maria Pellegrini, Itala Maria Loffredo D'Ottaviano (Eds.). Auto-organização: estudos interdisciplinares. Campinas: Coleção CLE, v.66, p.161-180, 2014.

- Maria Eunice Quilici Gonzalez, Mariana Claudia Broens, João Antonio de Moraes. A virada informacional na Filosofia: alguma novidade para o estudo da mente?. Revista de Filosofia: Aurora (PUCPR. Impresso) , v.22, p.137-151, 2010.

Eloísa Benvenutti de Andrade:

- Master in Philosophy at State University of São Paulo, UNESP, Marília/São Paulo/Brazil.

- $\triangle$ Eloisabenvenutti@yahoo.com.br

- Relevant publications:

- João Antonio de Moraes, Eloísa Benvenutti de Andrade. Notas para uma Fenomenologia da Vida Informacional. In: Mariana Claudia Broens, João Antonio de Moraes, Edna Alves de Souza (Eds.). Informação, Complexidade e Auto-Organização: Estudos Interdisciplinares. Campinas: Coleção CLE, v.73, p. 115-132, 2015.

- Eloísa Benvenutti de Andrade. Corpo e Consciência: Merleau-Ponty, crítico de Descartes. UNESP, 2010. 143p. (Master's Degree Thesis).

- Eloísa Benvenutti de Andrade. O projeto epistemológico cartesiano. Kínesis (Marília), v. 1, p. 133-149, 2009.

- Eloísa Benvenutti de Andrade. Os fundamentos da ontologia de Descartes por Merleau-Ponty. Filogênese (Marília), v. 1, p. 85-96, 2008.

- Eloísa Benvenutti de Andrade, Fernando César Pilan. A noção de fluxo contínuo da experiência: contribuições de John Dewey Para a Ciência Cognitiva. Cognitio-Estudos (PUC-SP. Online), v. 5, p. 25/3-32, 2008. 


\section{Introduction}

The theme of digital citizenship is one of the most addressed topics when discussing Internet Governance ${ }^{1}$, an area of research that deals with laws and policies to govern the Internet's provision and use ${ }^{2}$. This debate is complex due to the fact that the Internet is constructed to enable an environment of instant cooperation with a global reach. The use of the Internet is also relatively inexpensive, can be accessed by various types of devices, and comprises a relationship between individuals-in-network in a decentralized way. In this relationship, the key significant element is the individual, as the Internet user acquires a hitherto unmatched potential for expression in the world and can more than ever actively participate in issues of global interest.

It is in this sense that the notion of digital citizenship proposed by Mossberger, Tolberg \& McNeal finds itself: "'Digital citizenship' is the ability to participate in society online" 3,4 . To participate in online society involves using the Internet in typical ways and with a basic know-how, because only in the context of competent, standard use will it be possible for users to engage in patterns of conduct that are consistent with the notion of digital citizenship. Thus, such notions involve the use of Informational and Communication Technologies (ICTs) in one's daily actions for public or private purposes.

Information philosopher Rafael Capurro 5 inquires: Is there a difference between being a citizen in the "physical" world and in the "digital" one? We share with his philosophy the idea that the "digital" world is only as an expression of being-in-the-world, which in the information age acquires the complement "-in-network". Innetwork, as an expression, encompasses that which takes place in the digitalization of daily activities that precipitate an individuals' immersion into the digital environment, an environment that enables virtual relationships, e-commerce, home office space, social networks, e-Learning, and more. We believe that "physical" and "digital" are two faces of the same coin. To understand both sides, it is necessary, as Capurro argues, to go beyond moral and legal traditional paradigms that govern current civilization in order to encompass a new kind of being-in-the-world-in-network, a world familiarized by phenomena such as Wikileaks and the Snowden revelations.

According to Quilici-Gonzalez, Kobayashi, Gonzalez \& Broens ${ }^{6}$, Kantian Deontologism presents limitations in the analysis of ICTs' impacts in everyday life, since very few guide their behavior by "maxims" or "universal law". Floridi ${ }^{8}$, in turn, believes that, given its anthropocentric aspect, such a perspective would not be broad

\footnotetext{
${ }^{1}$ Although we do not aim to scrutinize the goals of Internet Governance research in this article, but only to discuss the topic of digital citizenship, we point out here other objects of interest of this research area, such as digital divide, free speech, free access, censorship, and responsibility. Roughly speaking, the discussions on these topics seek to analyze the current scenario and to identify disparities of access, the use of information, and knowledge in the digital environment (digital divide - economical and technical issues); the gratuity of the information available on Internet (free access); the control of the available content (free speech and censorship), the development of legal actions, and to identify accountability for failure to comply with current regulations (responsibility).

2 Dubois, Elisabeth, and Dutton, William H.: Empowering Citizens of the Internet Age: The Role of a Fifth Estate. 238

${ }_{3}^{3}$ Mossberger, Karen, and Tolberg, Caroline J., and McNeal, Ramona S.: Digital Citizenship - the Internet, Society, and Participation. 1

${ }^{4}$ It is worth noting that we are not regarding the notion of digital citizenship as "better" or "worse" than citizenship's traditional notion. In our discussion of digital citizenship, we seek only to analyze this notion as a result of a new possibility for an individual expression in the world. Such expression will be illustrated by popular participation through ICTs towards claiming individual rights. Therefore, those individuals who do not have an effective interaction with the digital environment will not be characterized as digital citizens. However, this does not imply any loss. Currently, although a large proportion of individuals still do not have Internet access, limiting their scope of digital citizenship, there is an exponential increase in the number of networked individuals. In 2014, for instance, there were more than three billion people with Internet access, constituting $40 \%$ of the world population. Moreover, the passage from two to three billion occurred only in four years, from 2010-2014 (http://www.internetlivestats.com/internet-users/).

${ }^{5}$ Capurro, Rafael: Citizenship in the Digital Age. Forthcoming

${ }^{6}$ Quilici-Gonzalez, José Arthur, and Kobayashi, Guiou, and Gonzalez, Maria Eunice Quilici, and Broens, Mariana Claudia: Ubiquitous computing: any ethical implications?

${ }^{7}$ Kant, Immanuel: Fundamental principles of the metaphysic of morals.

${ }^{8}$ Floridi, Luciano: Information ethics: on the philosophical foundation of computer ethics.
} 
enough to investigate digital-wide issues such as cybercrime, virtual vandalism, among others. As Capurro notes:

"Kant [...] can't walk a mile in our cybershoes. It seems we can't 'go home again' to the land of traditional ethics as the paradigms and parameters (as per Thomas Kuhn) have changed and are constantly changing. i.e. netiquette is of a different informational order/category to [physical] world etiquette. Snowden's 'theft' is of a different order to the felony of pilfering material property. Wikileaks activity is, from within the cyberworld, not stealing secrets but enabling access and devolving control - a positive social and communal and informational good"s.

We will thus argue in the following paper that a first step towards a clarification of the notion of digital citizenship is the identification first of who is it we refer to when we speak of the citizen and secondly to whom can be assigned digital citizenship status, a status of citizenry that overcomes the dichotomy between "physical" and "digital". Our hypothesis is that this citizen is a hybrid being that arises from the dynamic feedback relationship between his/her physical and digital experiences and the incorporation of a hybrid identity, an identity which is not only an alter ego or an avatar, but also an effective expression of being-in-the-world. It is this hybrid being who is capable of acting in the world in both forms of expression without incongruity, thus fully engaging his/her role as a digital citizen.

To ask about the notion of citizenship in the Digital Era is to, by default, ask about the rights and duties of hybrid being, where rights involve norms and laws for the regulation of the digital environment, but without neglecting the rights and duties of the individual in their physical space and environment. Using digital media towards greater participation in political decisions, individuals can position themselves actively. Thus, there is a bottom-up cooperation in the establishment of a digital community of individuals-in-network; through such community they can discuss and contribute effectively to the future paths of the information society ${ }^{10}$. As we will argue, it is precisely when the individual, as a hybrid being, acts in the physical/digital world engaged in popular participation that he/she earns his/her status as digital citizen.

In order to develop a hypothesis according to which hybrid beings are characterized as individuals who are the citizens of digital citizenship, we have structured this paper into three parts. First, we revisit the traditional notion of citizenship, a notion that focuses on the physical location to which the individual is located, corresponding to their rights and duties as such. As mentioned, such a notion does not clearly suit a notion of citizenship that is at the same time physical and digital, mainly due to the global-scale aspect of the digital environment. For this reason, in the second part, we make explicit the notion of hybrid being. We present new political possibilities of action performed by hybrid beings, featuring popular participation in the digital environment as resulting in the emergence of the Fifth Estate. Such participation, although set in a digital context, reflects, and is closely related to, the physical range of events. Finally, we draw some considerations around the relationship between digital citizenship, hybrid beings, and the Fifth Estate.

\section{Traditional Citizenship}

According to its etymology, the word "citizen" originates from the word civita, which in Latin means "city". This, in turn, is correlated to the Greek word politikós, meaning "the one who dwells in the city". In Ancient Greece the notion of citizenship was understood as a right that Greek individuals had to participate in decisions about the city's goals through Ekklesia, a practice enacted in the Ágora (Greek public square for the agreement of decisions). From this practice came Greek democracy, a type of democracy specific to only a few individuals whose decisions determined the destiny of the entire city (slaves, women, and artisans were excluded from citizenry).

\footnotetext{
${ }^{9}$ Capurro, Rafael: Citizenship in the Digital Age. Forthcoming

${ }^{10}$ Dyer-Witheford, Nick: Cycles and circuits of struggle in high-technology capitalism. 232
} 
In modern democracy, the notion of citizenship relates the practice of civil, political, and social rights and duties established by foundational national documents by which rights and duties interrelate to ensure a democratic society. In this way, the interrelationship of rights and duties also ensures that citizenship, to some extent, is inextricably linked to location, to where the individual performs his/her rights and duties. Consequently, citizenship requires from the individual not only his/her attention of their rights and obligations, but also his/her belief in democracy as an adequate political model, to practice it properly and fight to put it into practice. The model demands a reciprocity that ensures a give-and-take relationship between state and citizen and an adherence to established rights as protected through participation.

Thus, on the one hand, to be a citizen is to have the guarantee of all civil, political, and social rights so that the possibility of a full life is assured. On the other, it is understood by the citizen that such rights are not simply conferred; they are required, integrated, and then assumed by the laws, authorities, and local population in general. In other words, citizenship is not something given to the individual, but rather something built on a process of organization, participation, accountability and intervention by the individual.

The distinction between formal citizenship and substantive citizenship is made, where formal citizenship concerns that which is present both in foundational national documents and in other laws specific to particular countries, while substantive citizenship concerns actions that are performed in daily life. The enactment of substantive citizenship reveals that, despite laws ensuring formal citizenship, there would be no equality of said rights in daily life as outlined by the law, and thus no possibility to put citizenship into practice towards the improvement of democracy among all individuals without the actual practice of those rights being the basic foundation to citizenship.

As Thomas Marshall ${ }^{11}$ explains, the contemporary paradigm of citizenship first developed in the seventeenth and eighteenth centuries with the promulgation of so-called civil rights. In that context, the intention was to guarantee rights such as the right "to come and go", the right "to property", to "contractual freedom", "the freedom of religion and thought", and finally "to justice", where justice serves as a safeguard for all preceding rights. These rights informed European legislation, but without necessarily ensuring that civil rights where equally distributed to all people. Thus, this notion of citizenship was restricted to only individuals who owned properties or, especially, lands ${ }^{12}$.

Marshall elucidates the restriction of the notion of modern citizenship through its connection to capitalism, the well-known political-economic model that consolidates distinctions between social classes. Such an approach is a key point for comprehending the notion of digita/citizenship, especially as it pertains to discussion around who qualifies as a digital citizen. As Marshall points out:

"Citizenship is a status bestowed on those who are full members of a community. All who possess the status are equal with respect to the rights and duties with which the status is endowed. There is no universal principle that determines what those rights and duties shall be, but societies in which citizenship is a developing institution create an image of an ideal citizenship against which achievement can be measured and towards which aspiration can be directed. [...] Social class, on the other hand, is a system of, inequality. And it too, like citizenship, can be based on a set of ideals, beliefs and values. It is therefore reasonable to expect that the impact of citizenship on social class should take the form of a conflict between opposing principles. If I am right in my contention that citizenship has been a developing institution in England at least since the latter part of the seventeenth century, then it is dear that its growth coincides with the rise of capitalism, which is a system, not of equality, but of inequality. [...] What made it possible for them to be reconciled with one another and to become, for a time at least, allies instead of antagonists? The question is a pertinent one, for it is dear that, in the twentieth century, citizenship and the capitalist class system have been at war. "13

\footnotetext{
${ }^{11}$ Marshall, Thomas H.: Citizenship and social class. 10

12 Marshall, Thomas H.: Citizenship and social class. 35

${ }^{13}$ Marshall, Thomas H.: Citizenship and social class. 28-29
} 
Scholars of both English and French convention have traditionally defended the idea that human beings are born free and equal ${ }^{14}$. It is common even in modern conversations around citizenship to adopt this assumption as necessarily foundational to citizenship, thus ensuring individuals are guaranteed their rights and that said rights are ultimately indisputable. The challenge in a globalized, and especially a digitally globalized society is to reconcile the presumed foundations of classical citizenship with the current political-economic paradigm that severely undermines the individuals' freedom.

Thomas Hobbes ${ }^{15}$ argued that individuals, otherwise equal by nature, but having freedom, fight against each other in defense of individual interests. Thus an agreement (contract) between them is needed in order to prevent them from destroying themselves in their freedom. According to Hobbes, members of society should renounce their freedom and give to the State the right to act on their behalf in order to curb all excesses. On the other hand, according to John Locke ${ }^{16}$, only free and equal individuals have the ability to make a pact with the objective of establishing a political society. For Locke, such individuals are those who have some property to protect. For Rousseau ${ }^{17}$ equality is only meaningful if based on freedom, and according to his definition, equality can only be conceived from a legal perspective, i.e., everyone must to be equal before the law. In other words, individuals are not equal by being born equal and free, but because they have the same rights under the law, the law being constructed by those who administer a particular society. From this idea, the notion was first conceived that equality could prove a serious threat to the social privileges of the bourgeoisie and aristocracy, namely those who had for centuries maintained power and control. This realization was the catalyst to a developing discussion around the relationship between freedom and equality, a discussion that, with the dawn of the capitalist society, would side with freedom as the most valuable prerogative, leaving equality aside.

However, in this context, Karl Marx ${ }^{18}$ notes that the working class did not identify themselves as citizens because the concept of citizenry was reserved for the bourgeois individuals' representation only. For Marx, the idea of democracy would have to pass a criterion of social equality that only revolution could bring to reality, since political and human emancipation where unfamiliar concepts at the time. Although there are several theories as to the catalyst that set in motion the modern western achievement of democracy, it is commonly accepted that the nineteenth century human rights conquest by the working class, along with the growing understanding that human rights are not a "gift of nature" but the result of the struggle against the privileges of the elite, were key factors to the process.

We believe that the discussion around digital citizenship and the quest for an adequate political model for the digital world is critical. As Eduardo Colombo ${ }^{19}$ argues, it is possible to define, as a political field, the issues stemming from the collective action of a global society. The Proudhon defense follows that: "In a natural order, power born from society is the result of all particular forces joined: work, defense, and justice" ${ }^{20}$ Unlike the capitalist political-economic model in which there is a process of alienation producing a power structure of social domination, we agree with Colombo that, "The stateless society, without political power or domination, is a new way to win. It is the future" ${ }^{21}$.

Our contention is that the shape of this future will be found in the information society, a society in which ICTs determine the course of individuals' daily lives, especially as relating to the Internet. As such, the shape of

\footnotetext{
${ }^{14}$ For instance: Tocqueville, Alexis: Democracy in America.

${ }^{15}$ Hobbes, Thomas: Leviatã ou Matéria, Forma e Poder de um Estado Eclesiástico e Civil. 105

${ }^{16}$ Locke, John: Dois tratados sobre o governo. 406

${ }^{17}$ Rousseau, Jean-Jacques: Do contrato social. 9

${ }^{18}$ Marx, Karl: A Questão Judaica - Manuscritos Econômico-Filosóficos. 63

${ }^{19}$ Colombo, Eduardo: Análise do Estado: o Estado como paradigma de poder. 80

${ }^{20}$ Proudhon, Pierre-Joseph: De la Justice dans la Révolution et dans I'Eglise. 491 (our translation)

${ }^{21}$ Colombo, Eduardo: Análise do Estado: o Estado como paradigma de poder. 80-81 (our translation)
} 
citizenship must supersede traditional categories. A confrontation with traditional structures of citizenship categories is inevitable since such categories cannot be applied uniformly across the dynamic digital spaces being constructed and supported in a global bottom-up cooperation and interaction between individuals. The very nature of the digital community expresses a genuine power and an original sociability that exercises more influence in greater measure than any traditional citizenry and governance structure. The resources and opportunities for communication offered through ICTs allows for a confluence of "democratic" ideals that form in a digital global space in more efficient and rapid ways than through more traditional means of social power found in notions of "city state" citizenship expressed in the daily life and public meetings for which the foundational national documents of countries were prepared. In Deleuzian terms, the participation of individuals in the Internet context is configured as "nomadic", a term referring not only to someone who moves and to whom categorizations of locale cannot be applied, but to an ideal that does not allow itself to be coded by governing structures ${ }^{22}$, the expressions of which the digital citizen exemplifies. ${ }^{23}$

Thus, the question of the re-application of citizenship is raised. Who is the individual thus established as a citizen through the expression of rights and duties in a digital environment? To whom can digital citizenship status be applied? As we argue in the next section, such an individual is a hybrid being, a physical being connected to others in a digital space who, with other hybrid beings, is commonly seeking for rights, recognition and purpose in a borderless and non-nationalistic setting through the expressing their actions in the physical/digital world as digital citizens. The relationship between beings-in-the-world-in-network, from a bottom-up movement, denotes an empowerment for participation in discussions of local and global interest, in physical and digital environments. This active participation of individuals in the digital/physical context constitutes, as we share with Dubois \& Dutton ${ }^{24}$, the Fifth Estate, being the result of a cooperative organization between users themselves, as hybrid beings, playing their roles as digital citizens.

\section{ICT and Hybrid Beings}

The insidious increase and dominant presence of ICTs in individual everyday life remains largely unanalyzed. However, among the characteristics of ICTs, we wish to highlight and explore the following four novel aspects:

(i) New ways to manipulate information;

(ii) New kinds of interaction - online (indirect and anonymous);

(iii) The increasing capacity to capture, review, store, protect, and share information;

(iv) The global exponential spread of information.

Because of the increasing presence of ICTs in the individuals' daily life, new ways of being-in-the-world are emerging, changing current habits and influencing the way that individuals act and understand themselves in the world, both in relation to other individuals and to their environment. The Internet stands out as a catalyst to digital being-in-the-world, encompassing the above noted characteristics (i)-(iv). One of the most noteworthy and prominent changes associated with the influence of ICTs over individuals is in terms of communication, where individuals, who were until recently only receivers of information, have now become producers of information for a global network. In doing so, the new communication paradigm changes one's conception of the world and they become both actor within, and catalyst to, an immersed digital environment, thus constituting a bottom-up movement that is decentralized, an environment by which users are active participants.

\footnotetext{
22 Deleuze, Gilles: Pensamento nômade.

${ }^{23}$ As we explained in the introduction and in the footnote 4, we understand that the digital citizenship status could be assigned only to someone that know how to perform effectively in digital environment, participating in the development of the online society. As we also mentioned, there is not any initial loss in not has a digital citizenship, because it is a new possibility for individual expression in the world that not disregard the physical world and the citizenship's traditional notion. By way of we will explain latter, it is the constitution of the hybrid being that would mark the passage from citizenship and the possibility to perform the digital citizenship.

${ }^{24}$ Dubois, Elisabeth, and Dutton, William H.: Empowering Citizens of the Internet Age: The Role of a Fifth Estate.
} 
What little analysis has been offered towards understanding the influence that ICTs have had on the behavior of individuals and has been thus far largely restricted to user groups that include children and teenagers, namely the so-called Generation $Z$ (" $Z$ " in correspondence to zettabytes, the amount of information generated before 2010). ${ }^{25}$ These individuals, often called "digital natives", have never known access to a world without the presence and persistent influence of Google, Twitter, Wikipedia, and Facebook, where such terms are understood not as merely services but as verbs. ${ }^{26}$ Generation Z was born into, and raised, surrounded by ICTs, and all of the above 'novelties' of information and communication are rendered through natural actions in the case of digital natives. The intricate interaction with ICTs throughout the life of a Gen Z is based not in the formation of new behaviors but is based out of habits of action.

There is a naturalization of new forms of action in the world in the process of digitalization, much like there is in any new dynamic of society. As Capurro remarks, "The view of computers as something 'other' is disappearing, i.e., they are less and less 'some-thing' or 'other-than-us' and permeate the world in which we - or, more precisely: some of us - live". ${ }^{27}$ Moreover, with the development of ICTs and the disappearance of the boundary between physical and digital worlds, there is a direct influence of ICTs in the personal identity of individuals, where "in designing tools we are designing ways of being" 28 . As expressed by Ihde $^{29}$, there is a change in the life-world texture. It is precisely in this setting that the hybrid being appears as a result of the naturalization process and of the digitalization of the world, executing two expressions of the same world.

The hybrid being possesses three main characteristics ${ }^{30,31}$ :

(1) The absence of strangeness in facing new technologies;

(2) A natural development amid the physical/digital context;

(3) The constitution of personal identity mediated by ICTs.

Regarding the first point, we note that an individual's actions within a natural ICT-based context comprise both existing technologies and those that arise during the individual's growth. As indicated, children have now a great facility to handle informational artifacts without first having to conceive a world in which such artifacts do not exist. The second characteristic follows directly from the first, explaining the naturality in which the presence of ICTs is seen by younger individuals. Reminding a Gen Z about the dangers of privacy online regarding the sharing of information, photos, and personal videos on social networks is in many cases meaningless, since for, many Gen Z, opening sharing in a digital world is not only "natural", but concerns of privacy are not in fact "concerns" of theirs at all. ${ }^{32}$ Whether are not privacy should be a concern of theirs is another point altogether, and one has to now consider to whom it is that the concerns belong to, and whether those concerns are potent. Arising from (1) and (2), we note the dissolution of boundaries between "physical" and "digital" worlds, a dissolution that affects the personal identity of the individual in a world accessed via ICTs. As stated, such ontological considerations go beyond the mere sense of ICTs as tools, but now places such tools as intrinsically embedded objects within the dynamics of individual being-in-the-world. As we will argue, these dynamics promote the process of hybridization as a new expression of the being, the hybrid being, which will make possible the effectuation of digital citizenship.

\footnotetext{
${ }^{25}$ Gantz, John, and Reinsel, David: Extracting Value from Chaos.

${ }^{26}$ Floridi, Luciano: The Fourth Revolution - How Infosphere is Reshaping Human Reality. 43

${ }^{27}$ Capurro, Rafael: Interpreting the Digital Human. 8

${ }^{28}$ Winograd, Terry, and Flores, Fernando: Understanding Computers and Cognition. xi

${ }^{29}$ Ihde, Don: What Globalization Do We Want?. 84

${ }^{30}$ Floridi, Luciano: The Fourth Revolution - How Infosphere is Reshaping Human Reality.

${ }^{31}$ Capurro, Rafael: Interpreting the Digital Human.

32 Moraes, João Antonio de: Implicações éticas da "virada informacional na filosofia".
} 
In order to understand how ICTs can be intrinsically embedded within individual being, we look at the influence of ICTs on personal identity as developed by Floridi ${ }^{33}$, who identifies three kinds of self: personal identity (per se), self-conception and social self. Personal identity concerns effectively "who we are"; the self-conception is "who we think we are"; and the social self refers to "what we are from other people's thought". These three notions of self are closely related, and a change in one of them can also affect the others. The relationship between these notions of self is stressed in the following passage:

"Change the social condition in which you live, modify the network of relations and the flows of information you enjoy, reshape the nature and scope of the constraints and affordances that regulate your personality of yourself to the world and indirectly to yourself, and then your social self may be radically updated, feeding back into your self-conception, which ends up shaping your personal identity'34

In this sense, to conceive ICTs as mere tools is a naive conception, given their all-encompassing presence in the daily lives of millions of individuals, being an intricate part of their very existence. This mediation of individual's actions influences their existential self: while the experience of being-in-the-world is digitized there is also, as a consequence, the digitalization of their existence. As Capurro argues: "[ICT are] already part of the everyday life of millions of people. It is integrated in their bodily existence [...] if it is true that we change technology then it is also true that technology transforms us. This happens, indeed, at the very bottom of our bodily experience" ${ }^{35}$. It is worth noting that this understanding goes beyond the mere composition of individuals as cyborgs (i.e., to change the individual's body engaging an artifact), but as indicated, ICTs influence one's own understanding as being-in-the-world, in particular those connected to the Internet:

"[...] the ways we perceive reality and the thoughts we develop are shaped hermeneutically by our digital technologies and vice versa, digital technologies have to adapt to the ways we perceive and interpret reality. The Internet has brought up changes in our spatiotemporal social experience that were difficult to imagine some decades ago's6.

We understand that an individual's action of providing information about their selves in the digital environment constitutes a twofold action: co-constructing this environment and, at the same time, being built by it, influencing their self-understanding holistically but in different worlds, the digital world and the physical world; the way of hybrid being. It is through an individual's performance in the world, now expressed in its "physical" aspect, now "digital", that the hybrid being is conceived in its deeper meaning, going beyond notions of cyborg, alter ego or avatar. The underlying process to the constitution of hybrid beings can be outlined as follows ${ }^{37}$ :

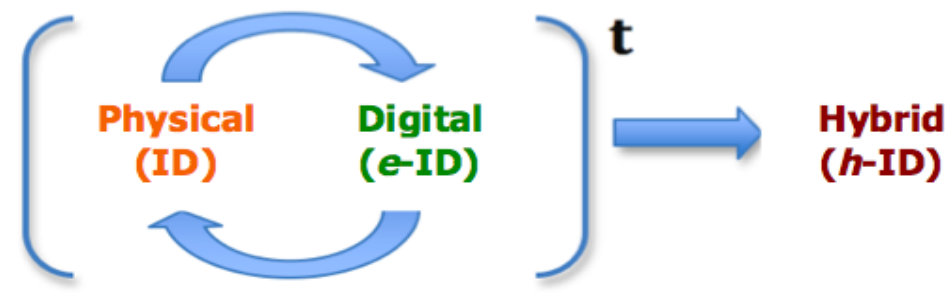

\footnotetext{
${ }^{33}$ Floridi, Luciano: The Fourth Revolution - How Infosphere is Reshaping Human Reality. 60

${ }^{34}$ Floridi, Luciano: The Fourth Revolution - How Infosphere is Reshaping Human Reality. 60-61

${ }^{35}$ Capurro, Rafael: Interpreting the Digital Human. 15

${ }^{36}$ Capurro, Rafael: Interpreting the Digital Human. 15

${ }^{37}$ Adapted from: Moraes, João Antonio de, and Andrade, Eloísa Benvenutti de: Notas para uma Fenomenologia da Vida Informacional. 126
} 
According to the above equation, an individual constitutes his/her personal identity (ID) from his/her experience in the physical world; that is, a way to recognize him/herself and interact with the world. Through the manipulation of ICTs and his/her immersion in the virtual environment, this individual discovers a range of possibilities for action, constituting his/her digital identity ( $e-I D)$; that is, his/her way of recognizing themself in the digital environment. Also related to $e-I D$ is an authentic expression of individualism dependent on anonymity and the choice of non-presence, enabling the individual to authentically behave in ways not possible in the physical world. Choice of being becomes approximation, especially in digital social relationships such as online chat where the individual controls both their actions and their presence of being. Online being also embraces both validation and space to be, free from the restrictions of localized, sub-cultural or national virtue and moral rebuke, examples being various states of exhibitionism and voyeurism not allowed in most physical sub-cultural or localized settings. In the course of time $(t)$ the dynamic between individual experiences, now in the physical, now in the digital, allows for an emergence of identity, both personal and digital, an identity in the end that has become unique. At this stage, it is not possible to distinguish between $I D$ and $e-I D$ in the individual's actions, constituting, therefore, a hybrid identity $(h-I D)$.

The hybrid being is characterized by his/her ability to act without strangeness in a context in which ICTs are disseminated. Thus, action and an individual's own personal identity is reinterpreted via mediation of ICTs, and this already becomes a part of his/her own existence. In other words, the hybrid being is the result of a process of an informational reinterpretation promoted by the inclusion of ICTs in the daily life of individuals, expressed in physical/digital dimensions. As far as citizenship goes, it becomes common for the hybrid being to presume the above physical/digital environments in any and all action. Where they act, as does any individual acting in any environment, the hybrid being reinterprets the dynamics of society through the lens of both localized and globalized contexts where national borders becomes less significant on one hand, but on the other hand, both localized contexts (i.e. the city, the home - namely the more intimate levels of the classical Greek ideas of economy), as well as globalized context (the global environment as precipitated by digital citizenship), inform participation in the decisions and directions of society. The most significant paradigm of the action of hybrid being is an emerging philosophy of activism and digital democracy, often referred to as cypherpunk philosophy, where global-wide citizen-participation seeks to ensure and protect the rights of individuals through information flow and information control. The cypherpunk philosophy is constructed around a dichotomy that demands, on one hand, a complete transparency of information by any and all authoritative bodies and governments, and on the other hand, the complete protection of information and individual privacy for the individual. ${ }^{38}$ It is a bold philosophy, but one that currently defies digital democracy, as best revealed through the recent WikiLeaks and whistleblowers phenomenon. The participation of hybrid beings acting as digital citizens results in the constitution of the Fifth Estate.

\section{Popular Participation and the Fifth Estate}

Since the Internet is a medium comprised of its users, where the information that the Internet consists of only exists in its active use by said users, and digital citizenship is the future of citizenship, such users are the necessary actors in the development of society in the Digital Era. Hybrids beings, classified as digital citizens, have a naturalized "ability to participate in society online" ${ }^{\prime 39}$. With the popular participation of the digital citizen, the digital environment presents itself as an important space for political discussion, given that the physical world's pressing problems are not only more widely discussed in online forums, but in fact such discussions first manifest their sources, as information, in digital casts, rather than analog ones. These real life events that transpire in the real world are claimed first in the digital environment, often times in un-delayed real-time documentation, where their digital being gains traction in ways unprecedented in traditional media, gaining total visibility ${ }^{40}$.

\footnotetext{
38 Hughes, Eric. A cypherpunk's manifesto.

${ }^{39}$ Mossberger, Karen, and Tolberg, Caroline J., and McNeal, Ramona S.: Digital Citizenship - the Internet, Society, and Participation. 1

${ }^{40}$ Dyer-Witheford, Nick: Cyber-Marx. Cycles and circuits of struggle in high-technology capitalism. 121
} 
In discussing the notion of digital citizenship, Fuchs ${ }^{41}$ develops a deep analysis around the concept of popular participation ${ }^{42}$ as seeking rights. Embedded in the digital environment, individuals share meanings constituting groups with common identities, even when users are from different physical locations, since the digital environment promotes dissolution of distance. When information is published on the Internet, often by individuals not officially associated with any official media forum, it has an "avalanche effect", a phenomenon often referred to as "going viral", incurring a global reach, the nature of which tends to be "spontaneous, unpredictable and uncontrollable". This effect is typical in situations of cyberprotest, for example.

In cyberprotest, the Internet can be used as a medium for discussion of goals and for coordination of activities to be performed. The digital environment is conceived as friendlier in terms of user participation, flexible, relatively inexpensive, fast, convenient, interactive, and enables equal participation among its users, being as it is, decentralized. In this context, people feel free to think and to contribute to the discussion ${ }^{43}$. There are also different approaches to the same information, enabling the expansion of political knowledge (unlike what happens in traditional mass media, which is a one-way road).

Fuchs describes cyberprotest as a self-organized, dynamical, networked, and global process ${ }^{44}$. Self-organizing processes have as the central feature the spontaneous dynamics between system's elements, without the presence of a central coordinator (internal or external) or a center absolute controller ${ }^{45}$. In this case, the Internet is the system, the users are the elements, and the cyberprotest is the result of a self-organizing dynamic among users in this digital environment. For its self-organizing aspect, the Internet is funded from a bottom-up movement. The self-organized aspect of the digital environment also corresponds to the hybrid nature of the digital citizen, "building" and to "being built by" this environment, carrying aspects of their physical environment. Thus, as an implication from the performance of hybrid being, as digital citizen, in contemporary society there is:

"[...] a self-organized society in which decisions are not alienated from those who are affected by them but are taken in inclusive bottom-up processes by affected citizens. They see ICTs as tools that support and empower political grassroots activism and participation. Protest movements use ICTs for communicating criticism and for voicing alternative opinions; their oppositional practices pluralize political opinions and guarantee a certain dynamic of democracy ${ }^{146}$.

In the process of political empowerment of individuals, the cyberprotest is characterized as a product of joint decisions ensured through network interaction. In its course, new individuals can enter the debate, others can leave, and the confluence of the dynamics remains relevant in terms of the event. ${ }^{47}$

We believe that the political empowerment of individuals, illustrated by cyberprotest, and developed mostly without any link to formal institutions and non-governmental organizations, is responsible for the constitution of the Fifth Estate. The following is the definition of the Fifth Estate proposed by Dubois \& Dutton ${ }^{48}$ :

"The Fifth Estate envisions the Internet as a platform through which networked individuals can perform a role in holding institutions such as the media and government more accountable. Network individuals

\footnotetext{
${ }^{41}$ Fuchs, Christian: Internet and Society - Social Theory in the Information Age.

${ }^{42}$ We are referring in this context to popular participation in the broad sense. The strict sense of such notion would involve the digital engagement together with interest, discussion, and political knowledge. Mossberger Tolberg, and McNeal strictly propose this characterization in: Digital Citizenship - the Internet, Society, and Participation. 48

${ }^{43}$ Mossberger, Karen, and Tolberg, Caroline J., and McNeal, Ramona S.: Digital Citizenship - the Internet, Society, and Participation. 52

${ }^{44}$ Fuchs, Christian: Internet and Society - Social Theory in the Information Age. 278

${ }^{45}$ Debrun, Michel: A ideia de auto-organização.

${ }^{46}$ Fuchs, Christian: Internet and Society - Social Theory in the Information Age. 294

${ }^{47}$ Fuchs, Christian: Internet and Society - Social Theory in the Information Age. 288-289

${ }^{48}$ Dubois, Elisabeth, and Dutton, William H.: Empowering Citizens of the Internet Age: The Role of a Fifth Estate.
} 
source information, independent of any single institution, using capabilities provided by search and social media. Users also create their own content in many forms, from posting photos on blogs to commenting on websites, providing even greater independence from other institutions and offering a mechanism whereby public opinion is directly expresses. [...] it is not simply a new media, such as an adjunct to the news media, but a distributed array of networked individuals to be used to challenge the media and play a potentially important political role. Composed of the distributed activities of one or many individuals acting on their own or collaboratively, but in a more decentralized network that crosses the boundaries of existing institutions". 49

In other words, the Fifth Estate is originated by individual efforts of the digital citizen networked and distributed with other citizens for whom the Internet has expanded his/her limitations. Once they become distributed, different actors, in different ways, can act on behalf of a common focus in order to achieve an effective impact. The Fifth Estate is the active participation of individuals, where hybrid being advocates for equality, collectively fulfilling the role of digital citizenship.

An example of the active involvement of digital citizens defending their rights as users in the digital environment is highlighted in the reaction to bill proposals PIPA and SOPA in 2010. PIPA (Protect IP Act) and SOPA (Stop Online Piracy Act) were intended to prohibit access to websites that offer copyrighted files as well as websites that exhibited download links of these types of files. The proposal of these bills resulted in a battle being fought between record companies, producers, and private institutions related to movies, on the one hand, and companies associated with the Internet, such as Google, Yahoo, Facebook, among others, on the other, in respect to private property in the digital environment ${ }^{50}$. Although the former initially possessed a majority in Congress, the bills were not approved due to the effective participation of users advocating on the Internet. Internet users conducted a cyberprotest against the approval of the bills, reaching a global audience within hours, causing a vocal global-wide opposition to PIPA and SOPA.

The importance of user participation in decisions regarding the referral of bills SOPA and PIPA, which involves issues of Internet Governance, is the fact that, although digitally born and digitally housed, the digital battle directly impacts the dynamics of the physical world. The impacts affect most the individual's privacy. If approved, such laws would become a mechanism to ensure compliance to the surveillance of individuals without their previous authorization.

Regarding cyberprotest, in this case in to bill C30 proposed in Canada, a bill that interferes in user's freedom to use the digital environment, Dubois \& Dutton indicate the emergence of the Fifth Estate as follows:

"A network of individuals opposed to legislation, united, not by institutionalized partisanship, but by opposition to increased surveillance of Internet use. These individuals were Internet users concerned that the proposed changes would affect their lives and the vitality of the Internet as a resource. They used the Internet strategically to oppose this legislation by harnessing their communicative power, enhanced by the Internet. [...] They show how a distributed group of networked individuals could provide new information, bringing in new participants with differing opinions to hold the government to account using multiple strategies and Internet application"51.

In the dynamic interactions of cyberprotest, critical levels of influence and change are quickly reached. According to Fuchs, unlike traditional, and specifically conservative protests, it is precisely the kind of momentum offered by cyberprotest, a momentum generated by digital citizenship that leads society towards positive developments for individuals:

"Critical protest is oriented towards the future; it identifies possibilities within existing society that help to improve the situation of mankind and to reach a higher and progressive level of societal organization.

\footnotetext{
${ }^{49}$ Dubois, Elisabeth, and Dutton, William H.: Empowering Citizens of the Internet Age: The Role of a Fifth Estate. 239-240.

${ }^{50}$ Costa, Antonio Luis M. C.: Cercas no Ciberspaço.

${ }^{51}$ Dubois, Elisabeth, and Dutton, William H.: Empowering Citizens of the Internet Age: The Role of a Fifth Estate. 246-247
} 
Conservative protest movements are not oriented towards the future but towards the past or that which actually exists, that is, they don't want to substitute structures of domination by cooperative and participatory structures but rather want to conserve, transform, or rebuild domination"152.

\section{Final Considerations}

The central question of this article was: To whom can we assign digital citizenship status? As indicated, we believe that the individual who fulfills this role is the hybrid being. The hybrid being expresses themself in the physical/digital environment of ICTs and the Internet without strangeness in order to play a more effective role in pursuit of their rights and duties. It is in this new context of citizenship that possibilities occur for an empowerment of the individual and the constitution of the Fifth Estate.

We understand the context of action generated by ICTs to constitute a space in which hybrid beings, as digital citizens, can act cooperatively in claiming their rights. Within this space, individuals are not directly subjugated to the current political-economic model that, as mentioned above, prioritizes control over the individual and their information rather than considering equal rights and effective expression. When viewed in terms of its natural environment, the digital environment is characterized as the space for the establishment of a "stateless society without political power or domination".53 The digital environment promotes the emergence of a digital community in which the Fifth Estate is expressed and an authentic power and sociability is guided by direct democracy. In this sense, digital citizenship becomes an effective participation of individuals towards the future directions of society. However, the process is not automatic, nor is the Internet automatically synonymous with democracy and citizen engagement. As Margolis \& Resnick comment,

"Paradoxically, one of the hardest things to predict is whether the Internet will improve the quality of democracy by creating a more informed citizenry. We say paradoxically, because it seems obvious that because the Internet provides instant and almost cost-free information, it should enable the ordinary citizen to be fully informed about all relevant policy areas [...] We remain skeptical [...] To be sure, the Net is now and will continue to be a boon to those who already have an active and sustained interest in public affairs, but there is little evidence that the Internet by itself will increase the attentive public. "154

In other words, the Internet is not characterized as an "itself", but as a "themselves", once conceived as a self-organized process that presents an interactive dynamic between its users, consisting of users and through them, advocating on their behalf.

Since hybrid beings are citizens of a digital citizenship, we understand that digital education is a key aspect towards the effectiveness of this particular type of citizenship. As stated, participation in digital society requires more than the mere use of ICTs to be effective. It needs, at the very least, a basic know-how through which individuals become both immersed and informed in the nature of the digital environment, and this incorporated into their daily practices. For this reason, we understand that discussions around digital citizenship need focus on Generation Z as a central focus towards a digitally educated future since digital natives are those most naturally and intricately immersed in the digital environment being simultaneously formed, as they are, through both physical and digital expressions of the world.

The Institut für Digitale Ethik (IDE) has developed materials that can contribute to the clarification of the use of technology by younger individuals. The aim is to deal with questions such as "What does it mean to act responsibly on the Internet?"55. This material goes beyond the simple theoretical discussion about ethics and

\footnotetext{
52 Fuchs, Christian: Internet and Society - Social Theory in the Information Age. 290

${ }^{53}$ Colombo, Eduardo: Análise do Estado: o Estado como paradigma de poder. 81

${ }^{54}$ Margolis, Michel, and Resnick, David: Politics as Usual: The Cyberspace "Revolution". 212

${ }^{55}$ Grimm, Petra, and Neef, Karla, and Waltinger, Michael: Ethik macht klick Werte-Navi fürs digitale Leben Arbeitsmaterialien für Schule und Jugendarbeit. 4
} 
moral action, aiming to incorporate in practice how to handle ICTs. Hence, rather than discuss standards of appropriate behavior, it seeks to explore the possibilities of interaction within digital media for individuals of Generation Z, also clarifying its possible consequences. Therefore, IDE researchers have developed meetings in schools with teachers and parents. The initial assumption is that with an approximation of younger audiences to this type of theme is possible, over a certain period of time, to generate a more conscious society, especially regarding the impact of ICTs usage and presence of the Internet in their daily lives. According to Capurro, this digital education is important because:

"[Digital environment] It's like the sea. The sea is always stronger, but you can learn to swim. However you can still drown, even if you have learned to swim well. But the swimming was incorporated. [...] One can also learn to swim in digital chaos - and even have fun doing it, once one belongs to it. If one has incorporated a digital ethics, one acts skillfully. Such a thing is what we call character. "56

When we use the term education, it is not in a functional connotation, but rather as a tool for social transformation of emancipatory and libertarian potential. We understand digital education as a way to operate a bottom-up movement within the constitution and design of the pathways of the information society, also contributing to the emergence of the Fifth Estate.

With the development of a digital education and the constitution of the Fifth Estate, we have, within the future actualization of the Internet, an original proposal towards the development of a space of horizontal rather than hierarchical interactions. For the time being, the proposal seems to be suppressed by particular interests of private companies like Facebook and Google. As occurs in the world of "physical" expression, where private companies and big investors vie to govern the future paths of the world, similar power plays occur amid "digital" environments. Interested companies share the common goal of governing the Internet as a whole, reducing the entity of the Internet to Facebook and/or Google monopolies only. This reductionist vision of the Internet breaks with the principle of horizontality and equality for users. It may happen that the information shared by these mediums, usually understood as common, are censored or used to maintain the privileges of some sectors of society. Another factor of concern is over the monopolization and potential abuse of big data where the presence of algorithms drives content received from users, both in feeds from Facebook and from results of searches performed on Google.

In conclusion, we believe that the efficiency of digital citizenship can promote a change in how individuals, now conceived as hybrid beings, relate to the world interpreted via ICTs. Such an actualization can be achieved with special attention paid to individuals of Generation $Z$ aimed at emancipation of such individuals from their actions in the physical/digital world, and going beyond a reductionist view of an Internet dependent on mediation via private companies and governments. Thus, we look towards an expression of the Fifth Estate in the direction of the future paths of the information society.

\section{Acknowledgments}

We would like to thank Amanda Garcia, Fernando Strongen, Nathália Pantaleão, and Pedro Bravo for the careful and critical reading of the above chapter. We would like to also thank our anonymous referees for the provocative suggestions that made possible the clarification of our ideas. We also thank Jared Bielby for the insightful remarks and English revision. Finally, João Antonio de Moraes thanks FAPESP (2014/03157-0), and CAPES (99999.010716/2014-09) for funding the above research.

${ }^{56}$ Küchemann, Fridtjof. Schwimmen im digitalen Chaos - Gespräch mit dem Info-Ethiker Rafael Capurro. (our translation) 


\section{References}

Capurro, Rafael. "Citizenship in the Digital Age". (forthcoming)

Capurro, Rafael: "Interpreting the Digital Human". Available at: http://www.capurro.de/digitalhermeneutics.html, 2010.

Colombo, Eduardo. Análise do Estado: o Estado como paradigma de poder. São Paulo: Ed. Imaginario, 2001.

Costa, Antonio Luis M. C. "Cercas no Ciberspaço". Carta Capital, n. 682, p. 30-33, 2012.

Debrun, Michel. "A idéia de auto-organização". Debrun, Michel, and Gonzalez, Maria Eunice Quilici, and Pessoa Jr, Osvaldo (Eds.). Auto-organização: estudos interdisciplinares. Campinas: Coleção CLE, v. 18, p.323, 1996.

Deleuze, Gilles. "Pensamento nômade". Marton, Scarlett (Ed.) Nietzsche hoje? Colóquio de Cerisy. São Paulo: Brasiliense, p.56-76, 1985.

Dubois, Elisabeth, and Dutton, William H. "Empowering Citizens of the Internet Age: The Role of a Fifth Estate". Graham, Mark, and Dutton, William H. (Eds.). Society \& the Internet. Oxford: Oxford University Press, 2014.

Dyer-Witheford, Nick. "Cycles and circuits of struggle in high-technology capitalism". Davis, Jim, and Thomas, Hirschl, and Stack, Michael (Eds.). In Cutting edge: Technology, information, capitalism and social revolution. London: Verso, p.195-242, 1997.

Dyer-Witheford, Nick. Cyber-Marx. Cycles and circuits of struggle in high-technology capitalism. Urbana: University of Illinois Press, 1999.

Floridi, Luciano. Information ethics: on the philosophical foundation of computer ethics. In: Ethics and information technology, v.1, p. 37-56, 1999.

Floridi, Luciano. The Fourth Revolution - How infosphere is reshaping human reality. Oxford: Oxford University Press, 2014.

Fuchs, Christian. Information and Society: Social Theory in the Information Age. New York: Routledge, 2008.

Gantz, John, and Reinsel, David. "Extracting Value from Chaos". IDC IVIEW, available at: http://www.emc.com/collateral/analyst-reports/idc-extracting-value-from-chaos-ar.pdf, 2011.

Grimm, Petra, and Neef, Karla, and Waltinger, Michael. Ethik macht klick Werte-Navi fürs digitale Leben Arbeitsmaterialien für Schule und Jugendarbeit. Available at: http://www. klicksafe.de/themen/medienethik/, 2015.

Hobbes, Thomas. Leviatã ou Matéria, Forma e Poder de um Estado Eclesiástico e Civil. Col. São Paulo: Abril Cultural, 1979.

Hughes, Eric. "A cypherpunk's manifesto." The electronic privacy papers. John Wiley \& Sons, Inc., 1997. Accessed September 29, 2015.

Ihde, Don. "What Globalization Do We Want?". Tabachnick, David, and Koivukoski, Toivo (Eds). Globalization, Technology, and Philosophy. New York: State University of New York Press, 2004.

Kant, Immanuel. Fundamental principles of the metaphysic of morals. Translated by Thomas Kingsmill Abbott. Available at: http://www.gutenberg.org/dirs/etext04/ikfpm10.txt, 1785.

Küchemann, Fridtjof. Schwimmen im digitalen Chaos - Gespräch mit dem Info-Ethiker Rafael Capurro. Available at: http://www. faz.net/aktuell/feuilleton/familie/gespraech-mit-dem-info-ethiker-rafael-capurro13509739. html, March, 25th, 2015.

Locke, John. Dois tratados sobre o governo. São Paulo: Martins Fontes, 2005.

Margolis, Michel, and Resnick, David. Politics as Usual: The Cyberspace "Revolution" Thousand Oaks, CA: Sage, 2000.

Marshall, Thomas H. Citizenship and social class. London: Cambridge University Press, 1950.

Marx, Karl. A Questão Judaica - Manuscritos Econômico-Filosóficos. São Paulo: Edições 70, 1975.

Moraes, João Antonio de. Implicações éticas da "virada informacional na Filosofia". Uberlândia: EDUFU, 2014. 
Moraes, João Antonio de, and Andrade, Eloísa Benvenutti de. "Notas para uma Fenomenologia da Vida Informacional". Broens, Mariana Claudia, and Moraes, João Antonio de, and Souza, Edna Alves de (Eds.). Informação, Complexidade e Auto-Organização. Campinas: Coleção CLE, v. 73, p. 115-132, 2015.

Mossberger, Karen, and Tolberg, Caroline J., and McNeal, Ramona S. Digital Citizenship: the Internet, Society, and Participation. Cambridge, MA: MIT Press, 2007.

Tocqueville, Alexis de. "Democracy in America". Levy, M. B. (Ed.). Political Thought in America: An Anthology. Chicago: Dorsey Press, 1988.

Proudhon, Pierre-Joseph. De la Justice dans la Révolution et dans l'Eglise. Paris: Garnier Frères, 1858.

Quilici-Gonzalez, José Arthur, and Kobayashi, Guiou, and Gonzalez, Maria Eunice Quilici, and Broens, Mariana Claudia: Ubiquitous computing: any ethical implications? In: International Journal of Technoethics, v. 1, p. 11-23, 2010.

Rousseau, Jean-Jacques. Do contrato social. São Paulo: Martins Fontes, 1999.

Winograd, Terry, and Flores, Fernando. Understanding Computers and Cognition: A New Foundation for Design. Norwood, NJ: Ablex Publishing Corp, 1986. 